\title{
Value Added Tax and Its Influence on Pricing and Price Decision Making of Companies - A Case Study
}

\author{
Anna Kubjatkova ${ }^{1, *}$, Anna Krizanova $^{1}$, and Veronika Jurickova ${ }^{1}$ \\ ${ }^{1}$ University of Zilina, The Faculty of Operation and Economics of Transport and Communications, \\ Department of Economics, Zilina, Slovakia,
}

\begin{abstract}
Pricing is a complex process that is influenced by many factors, which companies must constantly take into account when creating prices. The final selling price is formed by various influences, including the impact of value added tax (VAT). This tax affects all final consumers, but it also affects the businesses themselves in setting their sales prices. The main goal of this paper is to analyze the impact of VAT on pricing and to prove the fact that VAT values affect both the payer and the non-payer of VAT, if they buy from the VAT payer. The purpose is to point out the difference in the selling price between these two entities and thus to prove the influence of VAT on their pricing. In this paper, the methods of induction and deduction were used, as well as methods of analysis and synthesis. Based on the performed analyzes, we proved the influence of VAT on the pricing of both the payer and the non-payer of VAT, while the difference is observable in the amount of their selling price and tax liability.

Keywords: pricing, VAT, VAT payer, VAT non-payer, selling price
\end{abstract}

\section{Introduction}

It is in the interest of each state to control the tax compliance of all taxable persons, whether legal or natural persons. Taxes are the most important item of state budget revenue. Building an economically sustainable tax system is key to securing government activities [1]. An effective tax system creates the conditions in the country for a quality business environment necessary for the growth of a market economy [2]. All taxpayers are therefore equally important, and it is not just a sector of trade that is considered to be the power of the economy, especially in developing countries [3].

The tax system of the Slovak Republic consists of direct and indirect taxes. Direct taxes include income tax, real estate tax, or motor vehicle tax. In the case of direct taxes, the person is obliged to pay them and pay them to the state budget, while in the case of an employee-employer relationship; the employer is obliged to pay this tax on behalf of the employee. The principle of payment of indirect taxes is that one person pays them and the other person makes payment to the state budget. Indirect taxes consist of value added tax

*Corresponding author: anna.kubjatkova@fpedas.uniza.sk 
(VAT) and other excise taxes, while indirect taxes especially VAT, are, according to Kufelova [4] a more important component of the state budget than direct taxes. Therefore, tax audits are also carried out more frequently under indirect taxes. The reason is also that with VAT the possibility of tax evasion is much greater because VAT significantly more affects the solvency of individual tax subjects, which also affects the solvency of the state itself.

The risk of tax evasion is a constant threat in all countries, with taxpayers often aware of the fact that control authorities are severely limited in certain situations. According to Hybka, the risk of VAT evasion is also increased by the fact that the system and procedure for applying VAT to countries are often confusing and complicated [5].

VAT is an effective tool for the economy for several reasons. Author Cnossen [6] argues that, in general, VAT reduces the marginal cost of public finances and is thus an effective tool for increasing the tax ratio of countries that have included VAT in their tax system. According to author Adhikari [7], the effectiveness of VAT is also based on the assumption that this tax is designed effectively and is well enforceable. Loss of VAT effectiveness can occur, for example, in the exemption of small companies from VAT, or the exemption from VAT of problem-taxing agricultural and service companies in developing countries. The author notes in his research that most studies aimed at increasing the efficiency of VAT focus on high-income countries and therefore there is little evidence to assess the increase in VAT efficiency across rich and poor countries. Poorer countries have a much weaker VAT collection system, which means that the efficiency gains from VAT are questionable for them.

The pricing of a company depends on several factors, while its process is formed by a many pricing decisions, while the prosperity of not only Slovak companies is influenced by various important determinants [8]. The inherent influence of psychological aspects in pricing cannot be denied [9]. According to Valaskova, Kliestikova, and Krizanova [10] and Vatankhah, Zarra-Nezhad, and Amirnejad [11], not only knowledge of legislation but also consumer preferences is key to pricing. According to Chetthamrongchai and Saengchai [12] monitoring customer loyalty and loyalty and the factors that influence them also increase the efficiency of the pricing process and its outcome. The result of the company's pricing is an efficient pricing system and the selling price itself, in which all pricing decisions are reflected. The influence of VAT on the process of pricing and pricing of the company is clear in the final phase of creating and shaping the selling price. It is, therefore, necessary for companies to apply the VAT system correctly and to know its current rate.

The final customer and his satisfaction is the key to the long-term survival of the company [13] and as the final link in the retail chain, it is influenced by the amount of the selling price, while VAT is a part of it. However, this customer is often unaware of the presence of this component of the selling price and this affects his behavior. Several authors deal with the issue of the shopping behavior of customers in the Slovak Republic from different perspectives. The author Majerova [14] conducted a survey of the specifics of the behavior of Slovak customers on the Internet. The authors Gajanova, Nadanyiova, and Moravcikova [15] analyzed customer segments based on demographic and psychographic aspects. Researches by different authors from the environment of consumer behavior focused on green marketing is also a benefit in this area $[16,17]$. There is, therefore, a large amount of research in the field of consumer behavior in the Slovak Republic, but in the environment of this country, there is a great lack of studies dealing with the impact of VAT on the behavior of consumers or companies themselves. 


\section{Methodology}

The current amount of VAT in the Slovak Republic is regulated by Act no. 222/2004 Coll. on value added tax. This legal regulation recognizes 2 types of VAT, namely:

- $\quad$ basic VAT rate of $20 \%$,

- reduced VAT rate of $10 \%$.

A company needs to be able to assign the correct VAT rate to the goods or services it offers. According to the law, the basic VAT rate applies to all goods and services that are not subject to a reduced tax rate. According to legal regulation, the reduced tax rate applies to the following groups of goods and services:

- foods such as specific meat, fish or healthy foods,

- medicines and selected medical supplies,

- books, magazines, and periodicals,

- accommodation services [18].

\subsection{VAT payer vs. VAT non-payer}

Companies must distinguish between the payer and the non-payer of VAT, as this affects the selling price as a result of the company's pricing. A VAT payer in the Slovak Republic is an entity that:

- exceeded the turnover of $49790 €$ during 12 consecutive months of business,

- $\quad$ purchased goods or services from the EU whose total value in a calendar year exceeds $14000 €$.

A non-VAT payer is an entity that does not pay value added tax but does not use the right to deduct it. The most frequent non-payers of the tax are small self-employed persons, ie self-employed persons. Companies, non-profit and other organizations can also be nonpayers of value added tax [18].

An important issue in setting the price and thus in determining the selling price is not only whether the company itself is a payer or non-payer of VAT, but also whether the seller (supplier) is a payer or non-payer of VAT. It very often happens that a company, as a VAT payer, buys goods or a service from a non-VAT payer, and when it sells those goods or services to the final customer, the company no longer counts the sales amount with VAT but without VAT. It can be argued that the relationship that if a payer buys from a nonpayer, he also sells without VAT no longer applies. This error affects the selling price to a large extent, with the payer not paying value added tax to the State and thus committing tax fraud.

\subsection{Tax liability calculation method}

The value added tax return compares output tax (tax on the invoice issued to the supplier) and input tax (tax on the invoice received by the customer from the supplier). If the company has a higher amount of output, it means that it invoiced more for VAT than it has the amount on invoices received from the supplier, it means that the company has incurred tax liability. In this case, the company must pay to the state the amount it has calculated in the tax return. The opposite is the case of excessive deduction when the company has a higher amount of VAT on supplier invoices than the amount of VAT invoiced by the customer. In this case, the state will reimburse the company for the amount of the excess deduction [4].

To calculate the tax liability, the company must have have information such as:

- $\quad$ purchase price without VAT - purchase price of inputs without VAT,

- $\quad$ added value - operating costs and profit, 
- $\quad$ VAT rate $-20 \%$ (unless it is a reduced tax rate).

Tax liability calculation formula [18]:

$$
\text { TL = OVAT - IVAT }
$$

Where:

$T L=$ tax liability, $O V A T=$ output VAT, IVAT $=$ input VAT

The input VAT item is the relevant percentage (20\%) of the purchase price excluding VAT. The company calculates the output VAT item as an appropriate percentage $(20 \%)$ of the tax base [18]:

$$
\mathbf{T B}=\mathbf{P P W}+\mathbf{A V}
$$

Where:

$T B=$ tax base, $P P W=$ purchase price without $V A T, A V=$ added

The effect of VAT on a company's pricing is reflected in the selling price, which the company determines according to whether it is a VAT payer or a non-payer. Most business entities purchase material from another VAT payer, so the procedure is as follows. The VAT payer determines the selling price as follows [18]:

$$
\text { SPV }=\text { TB }+ \text { OVAT }
$$

Where:

$S P V=$ selling price with VAT

The VAT non-payer will determine his selling price according to the formula [18]:

$$
\mathbf{S P}=\mathbf{P P V}+\mathbf{A V}
$$

Where:

$S P=$ selling price, $P P V=$ purchase price with $V A T$

The difference between a payer and a non-payer is therefore obvious. Unlike the nonpayer, the VAT payer is also obliged to file a tax return for value added tax. Of course, companies determine the selling price as the optimal price to obtain the highest possible profit [19].

Classical procedures or even intelligent technologies can be used to calculate the tax liability. Their development and the creation of an integrated system can bring significant benefits not only in this area [20]. These systems can help make big data-based decisions to achieve results that can make the process itself time-saving [21].

\section{Results}

The impact of value added tax can be illustrated by a model example of a company, which we will mention once as a payer and once as a non-payer of VAT. The company buys material for the production of the product from the VAT payer. The purchase price of the material without VAT is $1250 €$. The company assumes a cost and profit of $700 €$ for this product. The rate of value added tax is basic, i.e. $20 \%$.

The calculation of the selling price of a product where the company is a VAT payer is shown in Table 1: 
Table 1. Calculation of the sales price of the VAT payer

\begin{tabular}{|c|c|}
\hline Item name & Amount in $\boldsymbol{€}$ \\
\hline PPW & 1250 \\
\hline IVAT & 250 \\
\hline AV & 700 \\
\hline TB & 1950 \\
\hline OVAT & 390 \\
\hline Selling price & $\mathbf{2 ~ 3 4 0}$ \\
\hline
\end{tabular}

Source: Own processing.

Tax liability $=390-250=240 €$

The calculation of the selling price of the product in case the company is a VAT nonpayer is shown in Table 2 :

Table 2. Calculation of the sales price of the VAT non-payer

\begin{tabular}{|c|c|}
\hline Item name & Amount in $\boldsymbol{€}$ \\
\hline PPV $($ PPW + IVAT $)$ & 1500 \\
\hline AV & 700 \\
\hline TB & 2200 \\
\hline OVAT & 0 \\
\hline Selling price & $\mathbf{2 2 0 0 0}$ \\
\hline
\end{tabular}

Source: Own processing.

If the company is not a VAT payer, its tax base is the purchase price as a whole, in which case it is the purchase price including VAT, as the company purchased from the VAT payer. If the company is a non-VAT payer, it has no tax liability, ie it does not file a VAT return.

We would like to emphasize that it is not possible to draw general conclusions from this case study, this research is aimed at providing an overview of the issue of the impact of value added tax on the payer and non-payer of VAT in specific conditions. This case study aims to provide information primarily to the general public through the analysis and processing of expertise.

\section{Conclusions}

In today's competitive environment, the importance of the company pricing process and its application on the market is growing. Properly set selling price is the key to gaining a competitive advantage and confirming market leadership. Therefore, companies must take into account all the factors that influence the creation of the selling price.

Based on the performed analysis, the difference in the sales price is visible, so it is appropriate to claim that VAT affects the company's pricing. Some companies also make pricing decisions based on VAT, which they have to take into account if they are VAT 
payers. However, it is clear from the example that non-VAT payers must also take into account the amount of VAT in the case of purchase from a VAT payer, so when purchasing material, non-VAT payers decide between VAT payers or non-payers as suppliers. Of course, to draw general conclusions, it is necessary to create additional simulations, which will be the subject of further research.

Pricing decisions and pricing of the company is a complex process, which is influenced by various factors, including the amount of VAT. Companies, whether or not they are VAT payers, must take their amount into account when creating the selling price of their products and services. In addition to being required to control the VAT calculation system, companies must also correctly determine the level of tax rate applied to specific products and services. Also, the control of the business relationship between the payer and the nonpayer of VAT is in practice a necessary part of functioning in the market.

This is paper is an outcome of project VEGA no. 1/0718/18: The impact of psychographic aspects of pricing on the marketing strategy of companies across products and markets.

\section{References}

1. M. Schratzenstaller, Sustainable tax policy: Concepts and indicators beyond the tax ratio. Obs. Diagn. Econ. 141(5), 55-77 (2015)

2. M. Buno, M. Nadanyiova, D. Hraskova, The comparison of the quality of business environment in the countries of Visegrad group. Procedia Economics and Finance, 26, 423-430 (2015)

3. J. Vrbka, E. Nica, I. Podhorska, The application of Kohonen networks for identification of leaders in the trade sector in Czechia. Equilibrium. Quarterly Journal of Economics and Economic Policy, 14(4), 739-761 (2019)

4. I. Kufelova, Ceny a cenove rozhodovanie. Bratislava: Wolters Kluwer. (2017)

5. M. M. Hybka, Collection dilemmas and performance measures of the value-added tax in Germany and Poland. International Journal of Management and Economics 54(2), 110-121 (2018)

6. S. Cnossen, VAT and agriculture: Lessons from Europe. International Tax and Public Finance 25(2), 519-551. (2018)

7. B. Adhikari, Does a value-added tax increase economic efficiency? Economic Inquiry. 58(1), 496-517, (2020)

8. K. Valaskova, T. Kliestik, M. Kovacova, Management of financial risks in Slovak enterprises using regression analysis. Oeconomia Copernicana, 9(1), 105-121 (2018)

9. K. Valaskova, V. Bartosova, P. Kubala, Behavioural aspects of the financial decisionmaking. Organizacija, 52(1), 22-32 (2019)

10. K. Valaskova, J. Kliestikova, A. Krizanova, Consumer perception of private label products: an empirical research. Journal of Competitiveness, 10(3), 149-163 (2018)

11. S. Vatankhah, M. Zarra-Nezhad, G. Amirnejad, An empirical assessment of willingness to accept "low-cost" air transport services: Evidence from the Middle East. Journal of Tourism and Services, 10(18), 79-103 (2019)

12. P. Chetthamrongchai, S. Saengchai, The impact of perceived service quality, customer perception and price strategy on pharmacy customer devotion. Polish Journal of Management Studies, 20(1), 139-148 (2019)

13. M. Nadanyiova, The Possibility of Introducing the CRM System in Railway Company Cargo Slovakia. 17th International Conference on Transport Means, 87-92 (2013) 
14. J. Majerova, Analysis of Specifics in Buying Behavior of Slovak Customers in Internet Environment. 2nd International Conference on Social Sciences Research, 5, 172178(2014)

15. L. Gajanova, M. Nadanyiova, D. Moravcikova, The Use of Demographic and Psychographic Segmentation to Creating Marketing Strategy of Brand Loyalty. Scientific Annals of Economics and Business, 66(1), 65-84 (2019)

16. D. Moravcikova, A. Krizanova, J. Kliestikova, M. Rypakova, Green marketing as the source of the competitive advantage of the business. Sustainability, 9(12), 2218 (2017)

17. J. Majerova, Analysis of Slovak Consumer's Perception of the Green Marketing Activities. 4th World Conference on Business, Economics and Management, 26, 553560 (2015)

18. Act no. 222/2004 Coll. Value Added Tax Act as amended.

19. V. Oliinyk, O. Kozmenko, I. Wiebe, S. Kozmenko, Optimal control over the process of innovative product diffusion: the case of Sony corporation. Economics and Sociology, 11(3), 265-285 (2018)

20. N. A. Zhuravleva, E. Nica, P. Durana, Sustainable smart cities: networked digital technologies, cognitive big data analytics, and information technology-driven economy. Geopolitics, History, and International Relations, 11(2), 41-47 (2019)

21. T. D. Meyers, L. Vagner, K. Janoskova, I. Grecu, G. Grecu, Big Data-driven algorithmic decision-making in selecting and managing employees: advanced predictive analytics, workforce metrics, and digital innovations for enhancing organizational human capital. Psychosociological Issues in Human Resource Management, 7(2), 49-54 (2019) 